\title{
Ethanol-induced ligand-independent activation of ERa mediated by cyclic AMP/PKA signaling pathway: An in vitro study on MCF-7 breast cancer cells
}

\author{
NICOLAS ETIQUE, STEPHANE FLAMENT, JULIE LECOMTE and ISABELLE GRILLIER-VUISSOZ \\ EA 3442 Aspects Cellulaires et Moléculaires de la Reproduction et du Développement, Nancy-Université, \\ Université Henri Poincaré, Faculté des Sciences, BP 239, 54506 Vandoeuvre-lès-Nancy, France
}

Received May 29, 2007; Accepted July 16, 2007

\begin{abstract}
Alcohol consumption is an increased risk factor for hormone-dependent breast cancer but the underlying molecular bases are unknown. Several studies suggest that ethanol could activate the estrogen signaling pathway. We have performed an in vitro study in order to investigate the molecular players involved in this phenomenon. Exposure of $\mathrm{MCF}-7$ breast cancer cells to ethanol induced an increase in the mRNA level of two well known estrogen target genes: progesterone receptor (PR) and $\mathrm{pS} 2$. This result was confirmed by an increase in luciferase activity in pEREtkLuc-transfected MCF-7 cells exposed to ethanol. These effects, whose intensity was similar to those of $\mathrm{E}_{2}$, were observed also in steroid-free medium and were inhibited by the antiestrogen ICI 182,780 . This suggested a ligand-independent activation of ER $\alpha$ that was confirmed by the absence of ER $\alpha$ proteolysis in ethanol-treated cells. Using PKA inhibitor (H89), the study of phospho-CREB by Western blot and transfection experiments with a CRE-reporter construct demonstrated that PKA was involved in ethanol-induced transcription of ER $\alpha$ target genes. Adenylyl cyclase inhibition impaired the activation of estrogen signaling pathway induced by ethanol. The results obtained in vitro, are discussed in regard to alcohol consumption and relevance to humans.
\end{abstract}

\section{Introduction}

Breast cancer is the most common cancer in women. About $70 \%$ of human breast cancers are related to sex hormone exposure and $60 \%$ of all patients have hormone-dependent breast cancer. These tumors express estrogen receptors (ER) and require estrogens for their growth (1-3). The effects of

Correspondence to: Professor S. Flament, Université Henri Poincaré-Nancy I, Faculté des Sciences, EA3442, Entrée 1B - 9ème étage, Boulevard des Aiguillettes, BP 239, 54506 Vandoeuvre-lèsNancy cedex, France

E-mail: stephane.flament@scbiol.uhp-nancy.fr

Key words: breast cancer, ethanol, estrogen receptor, PKA, cyclic AMP these hormones on tumor development are mediated by the receptor $\mathrm{ER} \alpha$, a member of the superfamily of steroid nuclear receptors that commonly function as ligandregulated transcription factors. In cells, ER $\alpha$ is associated in a protein complex containing heat shock protein 90, which prevents the association of the receptor with DNA. In the best understood mode of action, or 'classical pathway', ligand binding induces a conformational change of ER $\alpha$ and the dissociation of the protein complex. The liganded receptor then binds to specific estrogen response elements (EREs) within target genes and recruits a p160/p300 coactivator complex to the promoter $(4,5)$. This coactivator complex promotes gene transcription by remodeling chromatin and by contacting the basal transcription machinery. For instance, progesterone receptor (PR) and $\mathrm{pS} 2$ are two estrogen target genes that are often studied in breast cancer $(6,7)$. A second mode of action has been described in which, following hormone binding, the ER $\alpha$ could utilize unspecified proteinprotein interactions to enhance the activity of heterologous transcription factors such as AP-1 $(8,9)$ or Sp1 $(10)$.

In addition to these hormone-dependent ER $\alpha$ activations, hormone-independent activation also occurs in human breast cancer cells. Indeed, many studies have shown that ER $\alpha$ activity can be stimulated by modulation of several kinase pathways (11). As an example, the mitogen-activated protein kinase (MAPK) pathway activated by epidermal growth factor directly phosphorylates ER $\alpha$ in the absence of ligand and induces ER transactivation $(12,13)$. Similarly, ligandindependent ER activators can act via the protein kinase A (PKA) signaling pathway. Activation of PKA by 8-bromocyclic AMP, a stable form of cyclic AMP, and an activator of adenylyl cyclase, cholera toxin or forskolin, enhances ER phosphorylation and activity $(14,15)$.

Many epidemiological studies show that chronic alcohol consumption, even with a moderate dosage, increases significantly the incidence of breast cancer (16-19) and promotes mammary tumorigenesis $(20,21)$. Estrogens seem to be involved in these effects since the increased risk is associated with a higher frequency of ER-positive tumors. Moreover, in pre- and post-menopausal women, alcohol consumption increases the circulating level of estrogens and DHEA $(22,23)$.

In ER-positive breast cancer cells, several in vitro studies have shown that ethanol enhances cell proliferation (24-27). 
This effect was observed between $0.0001 \%$ and $1 \%$ depending on the study and the method used to analyze cell proliferation (24-27). We have demonstrated that this effect is associated with an increase in the expression of ER $\alpha$ and aromatase, the enzyme responsible for estrogen synthesis (27). Ethanol can also stimulate cell invasion $(28,29)$. Interestingly, we have recently shown in MCF-7, that ethanol increases MMP-9 secretion via ER $\alpha$ activation (30). These results suggest that the estrogen signaling pathway plays a key role in the effects induced by ethanol in breast cancer cells. Furthermore, it has been reported that ethanol increases estrogen receptor activity in MCF-7 (31). Thus, ethanol could act as an 'estrogenlike' compound on breast cancer cells but the interactions between ethanol and the estrogen signaling pathway are not clearly understood.

In the present study, we show that ethanol treatment stimulates the transcription of estrogen responsive genes in MCF-7 cells. We demonstrate that ethanol induces the cyclic AMP/PKA signaling pathway leading to the activation of $\mathrm{ER} \alpha$ in a ligand-independent manner. These results are discussed in regard to relevance for humans.

\section{Materials and methods}

Materials. Dulbecco's modified Eagle's medium (DMEM), L-glutamine and 17- $\beta$-estradiol $\left(\mathrm{E}_{2}\right)$ were purchased from Sigma-Aldrich (Saint-Quentin Fallavier, France) and fetal calf serum (FCS) from Eurobio (Les Ulis, France). ICI 182,780 was purchased from Tocris Cookson (Bristol, UK). H89 and SQ22536 were purchased from Calbiochem (La Jolla, CA). These chemicals were dissolved in ethanol. When added to the medium of ethanol-treated cells, the ethanol final concentration did not exceed $0.3 \%$. For non-ethanol treated-cells, the chemicals were diluted in medium with an ethanol final concentration $<0.01 \%$.

Cell culture and treatment. The MCF-7 (HTB 22; human breast adenocarcinoma, ER-positive) cell line was obtained from the American Tissue Culture Collection (Rockville, MD). Cells were routinely grown at $37^{\circ} \mathrm{C}$ in a $5 \%(\mathrm{v} / \mathrm{v}) \mathrm{CO}_{2}$ humidified atmosphere. They were cultured in DMEM supplemented with $10 \% \mathrm{FCS}$ and $2 \mathrm{mmol} / \mathrm{l} \mathrm{L}$-glutamine.

For RT-PCR analyses, cells were seeded in 6-well plates at a density of $8 \times 10^{4}$ cells/well in $2 \mathrm{ml}$ of DMEM supplemented with $5 \%$ FCS and $2 \mathrm{mmol} / \mathrm{l} \mathrm{L-glutamine.} \mathrm{After} 24 \mathrm{~h}$ of incubation to allow for cell attachment, the medium was replaced with phenol-red free DMEM supplemented with $1 \%$ FCS and $2 \mathrm{mmol} / \mathrm{l} \mathrm{L-glutamine.} \mathrm{After} 24 \mathrm{~h}$, the medium was eliminated and cells were washed three times with PBS. Cells were treated for $24 \mathrm{~h}$ with ethanol at different concentrations and/or various compounds in phenol-red free DMEM supplemented with $2 \mathrm{mmol} / \mathrm{l} \mathrm{L}$-glutamine with $1 \%$ FCS. Ligand-independent studies were performed in similar conditions but in serum-free medium.

For Western immunoblotting analyses, cells were treated in the same conditions but were seeded in $75 \mathrm{~cm}^{2}$ flasks at a density of $1.5 \times 10^{6}$ cells/flask.

Semi-quantitative RT-PCR. Total RNA was extracted from cells using TRIzol reagent (Invitrogen, Cergy Pontoise, France) according to the manufacturer's instructions. cDNA was synthetized in a $20 \mu \mathrm{l}$ volume containing $2 \mu \mathrm{g}$ RNA, $1.5 \mu \mathrm{g}$ random hexamer primer, $1 \mathrm{X}$ Invitrogen Buffer, 7,5 mmol/1 DTT, $0.6 \mathrm{mmol} / \mathrm{l}$ of each dNTP, $4 \mathrm{U}$ RNase inhibitor, and $100 \mathrm{U}$ of MMLV reverse transcriptase (Invitrogen). The mixture was incubated for $120 \mathrm{~min}$ at $37^{\circ} \mathrm{C}$ and subsequently for $5 \mathrm{~min}$ at $94^{\circ} \mathrm{C}$ in order to stop the reaction.

The cDNAs were further amplified by PCR. The specific primers were 5'-TGCTCAAGGAGGGCCTGCCGCAGGT-3' and 5'-CTACTGAAAGAAGTTGCCTCTCGCC-3' for progesterone receptor (32), 5'-TTCTATCCTAATACCAT CGACG-3' and 5'-TTTGAGTAGTCAAAGTCAGAGC-3' for pS2 (33) and 5'-TACATGGGTGGGGTGTTGAA-3' and 5'-AAGAGAGGCATCCTCACCCT-3' for $\beta$-actin (24). PCR was carried out in a thermal cycler in a final volume of $25 \mu 1$ containing $2 \mu \mathrm{l}$ cDNA, $1 \mathrm{X}$ Eppendorf Taq Buffer (Eppendorf, Le Pecq, France), 0.5X Eppendorf Taq Master, 1.5-2.5 mmol/l $\mathrm{MgCl}_{2}, 125 \mu \mathrm{mol} / \mathrm{l}$ of each dNTP, $0.33 \mu \mathrm{mol} / \mathrm{l}$ of each primer, and $0.5 \mathrm{U}$ Taq polymerase. Negative controls were always included. Amplification was carried out under the following conditions: $94^{\circ} \mathrm{C}$ for $5 \mathrm{~min}, 25-30$ one-minute cycles at $94^{\circ} \mathrm{C}$ ( 25 cycles for $\mathrm{pS} 2$ and $\mathrm{B}$-actin; 30 cycles for PR) $1 \mathrm{~min}$ at $54-65^{\circ} \mathrm{C}$, and $1 \mathrm{~min}$ at $68^{\circ} \mathrm{C}$, followed by a 10 -min extension step at $68^{\circ} \mathrm{C}$. For each gene, the amplification took place in the linear phase of the PCR reaction. The PCR products (25 $\mu 1)$ were mixed with loading buffer $(3 \mu 1)$ and submitted to electrophoresis in a $2 \%$ agarose gel at $90 \mathrm{~V}$ for $60 \mathrm{~min}$ at room temperature. The gel was stained with ethidium bromide, viewed and photographed on a UV-transilluminator (GelDoc 2000, Bio-Rad Laboratories, Marnes-La-Coquette). A software package (Quantity One v.4.3.1, Bio-Rad Laboratories) was used to quantify the PCR products.

Real-time PCR. Real-time PCR analysis was performed on a MiniOpticon System (Bio-Rad) by using SYBR-green labeling. RNA extraction and cDNA synthesis were performed as described above for semi-quantitative RT-PCR. Oligonucleotide primer sequences for PR, pS2 and RPLP0 were described previously $(34,35)$. Each sample was normalized on the basis of its RPLP0 content (RPLP0 is also known as 36B4 and encodes human acidic ribosomal phosphoprotein P0). Final results were expressed as the mean of the ratios: $\left(\mathrm{E}_{\text {target }}\right)^{\Delta \mathrm{C}} \mathrm{t}_{\text {target }}$ (control-sample) $/\left(\mathrm{E}_{\text {ref }}\right)^{\Delta \mathrm{C}_{\mathrm{t}}}$ (cof (control-sample) $(36,37)$.

Western immunoblotting. At the end of the treatment, cells were washed twice with cold PBS. Proteins were extracted with lysis buffer containing: $25 \mathrm{mmol} / \mathrm{l} \mathrm{MOPS} \mathrm{pH} \mathrm{7.2,} 60 \mathrm{mmol} / \mathrm{l} ß-$ glycerophosphate, $15 \mathrm{mmol} / 1$ nitrophenylphosphate, $15 \mathrm{mmol} / \mathrm{l}$ EDTA, $15 \mathrm{mmol} / 1 \mathrm{MgCl}_{2}, 2 \mathrm{mmol} / 1 \mathrm{DTT}, 0.1 \mathrm{mmol} / 1$ sodium orthovanadate and protease inhibitors $(10 \mu \mathrm{g} / \mathrm{ml}$ aprotinin, $5 \mu \mathrm{g} / \mathrm{ml}$ pepstatin, $10 \mu \mathrm{g} / \mathrm{ml}$ leupeptin, $10 \mu \mathrm{g} / \mathrm{ml}$ soybean trypsin inhibitor and $100 \mu \mathrm{mol} / \mathrm{l}$ benzamidine). After boiling $\left(100^{\circ} \mathrm{C}, 5 \mathrm{~min}\right)$, an aliquot was used for protein concentration determination. Thirty micrograms of total proteins were subjected to SDS-PAGE (10\%). After electrophoresis, proteins were transferred onto nitrocellulose membranes. The membranes were blocked in TBST buffer with 5\% non-fat powder milk (TBST-Buffer:Tris-HCl $50 \mathrm{mmol} / \mathrm{l}, \mathrm{pH} 7.4$, $\mathrm{NaCl} 150 \mathrm{mmol} / \mathrm{l}, 0.1 \%$ Tween-20) and incubated for $1 \mathrm{~h}$ with primary antibody. The anti-ER $\alpha$ (clone F-10, SC-8002, 
Santa Cruz, CA) was diluted at 1:250, the anti-phosphoCREB (clone 10E9, Upstate, UK) at 1:2000 and the anti-actin (Clone 22a, Santa Cruz) at 1:1000. After washing with TBST, the membranes were incubated for $1 \mathrm{~h}$ in peroxydaselinked secondary antibody (Santa Cruz), washed again and developed using a chemiluminescence method (Amersham, Orsay, France).

Transient transfection assays. MCF-7 cells were plated at a density of $5 \times 10^{5}$ cells in 6 -well plates in $2 \mathrm{ml}$ of DMEM supplemented with $5 \% \mathrm{FCS}$ and $2 \mathrm{mmol} / \mathrm{l} \mathrm{L}$-glutamine, and allowed to adhere for $24 \mathrm{~h}$. A 5:1 ratio of pCRE-SEAP or pEREtkLuc vector and $\beta$-galactosidase ( $($-Gal) control vector were cotransfected using Exgen 500 (Euromedex, France), as recommended by the manufacturer.

Three $\mu \mathrm{g}$ of pCRE-SEAP or pEREtkLuc and $0.6 \mu \mathrm{g}$ of B-Gal control vector were used for each well. The pCRESEAP vector contained the secreted alkaline phosphatase (SEAP) reporter gene, with 3 tandem copies of the cyclic AMP response element (CRE) consensus sequence that upon CREB binding could induce transcription and activation of the SEAP reporter. The pEREtkLuc vector contained the luciferase reporter gene, with one copy of the estrogen response element (ERE) consensus sequence that upon ER $\alpha$ binding could induce transcription of the luciferase reporter. The $\beta-G a l$ control vector contained the CMV promoter and enhancer sequences, and served as a control for normalization of transfection efficiencies. After transfection, cells were allowed to grow for $24 \mathrm{~h}$ in phenol-red free DMEM supplemented with $10 \%$ FCS stripped in dextran-coated charcoal and $2 \mathrm{mmol} / \mathrm{l}$ L-glutamine. Cells were then treated for $24 \mathrm{~h}$ in fresh medium. SEAP activity was measured by using the BD Great Escape SEAP detection kit (BD Biosciences, CA) and Luciferase activity by using the Bright-Glo Luciferase Assay System (Promega, Charbonnieres, France) as recommended by the manufacturer. $\beta-$ Gal activity was measured using the $\beta$ Galalactosidase Enzyme Assay System (Promega). SEAP and luciferase activity were detected using a luminometer and B-Gal activity using a spectrophotometer. SEAP and luciferase reporter activity was normalized with the $\beta$-Gal activity.

Statistical analysis. The results are expressed as mean \pm standard error of several experiments as indicated in the text. Differences among treatment groups were tested using analysis of variance (ANOVA). Statistically significance was set at $\mathrm{P}<0.05$. When significant differences were detected, specific post-hoc comparisons between treatment groups were examined with the Student Newman's Keuls test (SPSS v11.0 Computer Software).

\section{Results}

Ethanol stimulates the expression of ERa target genes. To investigate the involvement of ER $\alpha$ signaling pathway in ethanol activity, we studied two well known estrogen responsive genes: the progesterone receptor (PR) and pS2 $(6,7)$. Their expression was analyzed by semi-quantitative RT-PCR in MCF-7 breast cancer cells treated with various concentration of ethanol (0.1-0.7\% i.e. $17-119 \mathrm{mmol} / \mathrm{l})$ or $\mathrm{E}_{2}(1 \mathrm{nmol} / \mathrm{l})$ for

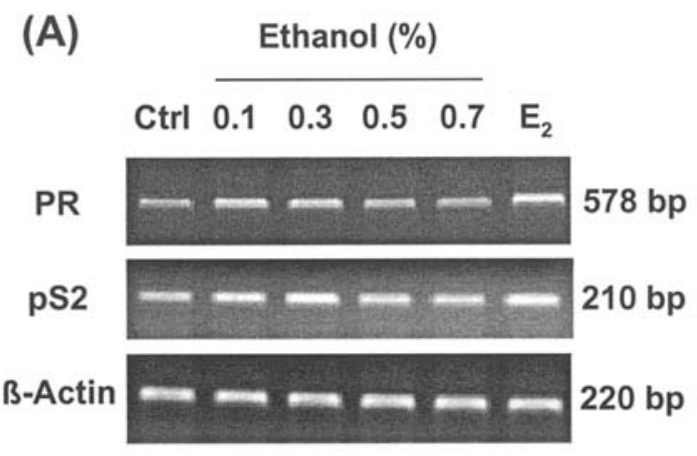

(B)

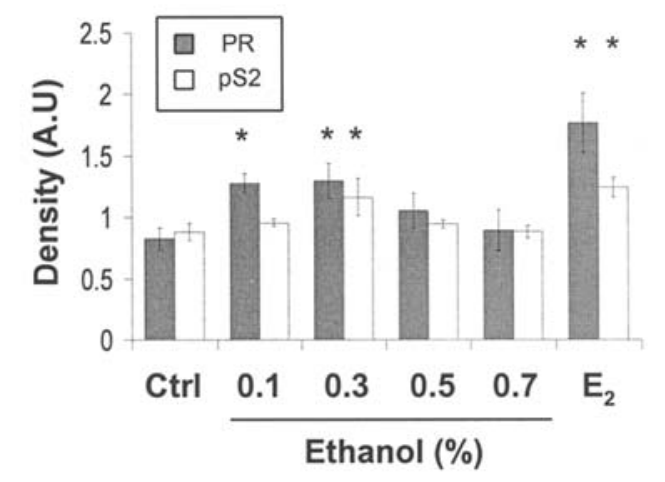

Figure 1. Ethanol stimulates the expression of two ER-responsive genes in MCF-7 cells cultured in 1\% FCS containing medium. (A) Semi-quantitative RT-PCR analysis of PR and pS2 mRNAs. MCF-7 cells were stimulated for $24 \mathrm{~h}$ with various concentration of ethanol (0.1-0.7\%) or $\mathrm{E}_{2}(1 \mathrm{nmol} / \mathrm{l})$. $ß$-actin mRNA levels were determined as an internal control. For each gene, the amplification took place in the linear phase of the PCR reaction. (B) The histogram represents the mean $\pm \mathrm{SE}$ of four separate experiments in which the band intensities of PR and $\mathrm{pS} 2$ were evaluated in terms of optical density arbitrary units (AU) and normalized with the B-actin signal intensity. *Significantly different from untreated control $(\mathrm{P}<0.05)$.

$24 \mathrm{~h}$ in $1 \%$ FCS containing medium (Fig. 1). In case of $\mathrm{E}_{2}$ stimulation, our results showed a significant 2.1-fold and 1.4-fold increase in the PR and pS2 mRNA levels, respectively, compared to control levels $(\mathrm{p}<0.05)$. In ethanol-treated breast cancer cells, we observed a significant 1.6-fold increase in PR mRNA level for either 0.1 or $0.3 \%$ ethanol and a 1.3 -fold increase in $\mathrm{pS} 2$ expression for a dose of $0.3 \%(\mathrm{P}>0.05)$. Since the dose of $0.3 \%$ was more efficient, we decided to use this concentration in the following experiments.

In order to determine whether ER $\alpha$ is involved in the ethanol-induced increase in PR and pS2 expression, we used an antiestrogen: the 'pure' antagonist ICI 182,780 (37). We have recently shown that this compound was able to block the $\mathrm{E}_{2}$-triggered increase in PR expression in MCF-7 cells with the best efficiency observed at the concentration of $100 \mathrm{nmol} / \mathrm{l}$ (30). By semi-quantitative RT-PCR analysis, we showed that at this concentration, ICI 182,780 inhibits significantly the increase in both PR and pS2 mRNAs expression induced by $\mathrm{E}_{2}(1 \mathrm{nmol} / \mathrm{l})$ as well as ethanol (Fig. 2). Besides, the level of PR mRNAs was lower than in control cells. This could be explained by the fact that ICI 182,780 binds to ER $\alpha$ and inhibits ER signaling not only by competition with the agonists but also by $\mathrm{ER} \alpha$ proteolysis 
(A)

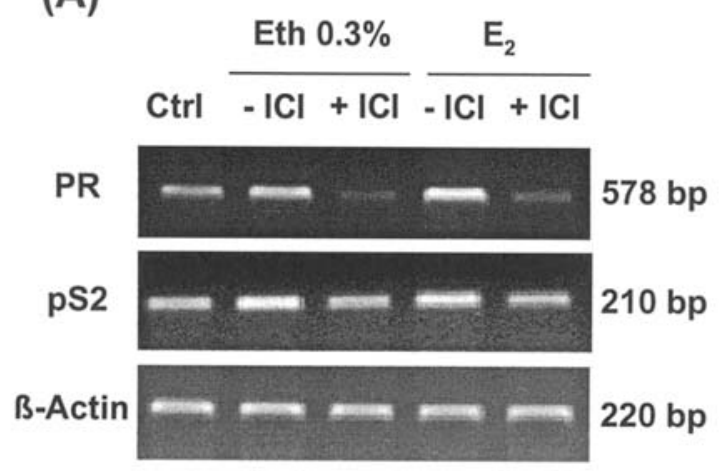

(B)

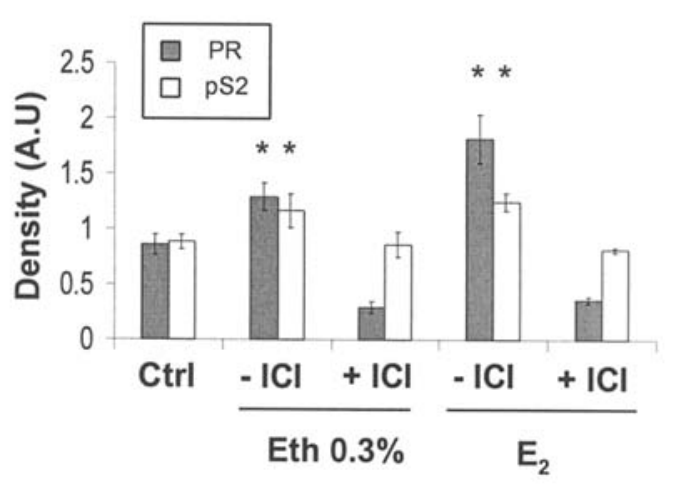

Figure 2. Induction of PR and $\mathrm{pS} 2$ gene expression by ethanol is inhibited by the pure antiestrogen ICI 182,780. (A) Semi-quantitative RT-PCR analysis of PR and pS2 mRNAs. MCF-7 cells were stimulated for $24 \mathrm{~h}$ with $0.3 \%$ ethanol (Eth) or $1 \mathrm{nmol} / 1 \mathrm{E}_{2}$ in the presence or absence of $10 \mu \mathrm{mol} / \mathrm{l}$ ICI 182,780 (ICI). $\beta$-actin mRNA levels were determined as an internal control. For each gene, the amplification took place in the linear phase of the PCR reaction. (B) The histogram represents the mean \pm SE of four separate experiments in which the band intensities of PR and pS2 were evaluated in terms of optical density arbitrary units (AU) and normalized with the $\beta$-actin signal intensity. ${ }^{*}$ Significantly different from untreated control $(\mathrm{P}<0.05)$.

induction (38). However, pS2 expression was similar to those of control cells suggesting that the $\mathrm{E}_{2}$ sensitivity of $\mathrm{pS} 2$ expression is different from those of PR in MCF-7 cells. These results demonstrated that ethanol is able to activate the estrogen signaling pathway in MCF-7 breast cancer cells and enhance the transcription of these $\mathrm{ER} \alpha$ target genes.

ERa activation by ethanol is ligand-independent. Our previous study showing that ethanol treatment leads to an increase in aromatase expression in breast cancer cells suggested that $\mathrm{ER} \alpha$ activation could be the result of an increase in local estrogen concentration (27). To test this hypothesis, we decided to use serum-free medium which does not contain steroid hormones. PR and pS2 expressions in MCF-7 cells treated for $24 \mathrm{~h}$ with ethanol $(0.3 \%)$ were analyzed by semiquantitative RT-PCR (Fig. 3A and B). In control cells, the level of PR expression was lower than in our previous experiment using 1\% FCS (compare with Figs. 1 and 2). This is consistent with the absence of steroids in the medium. pS2 expression was also decreased, but more modestly. This is in agreement with the lower sensitivity to $E_{2}$ of this gene in our conditions. Despite the absence of steroid hormones,

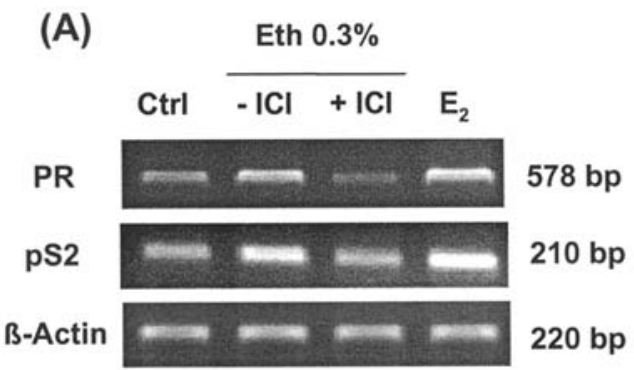

(B)
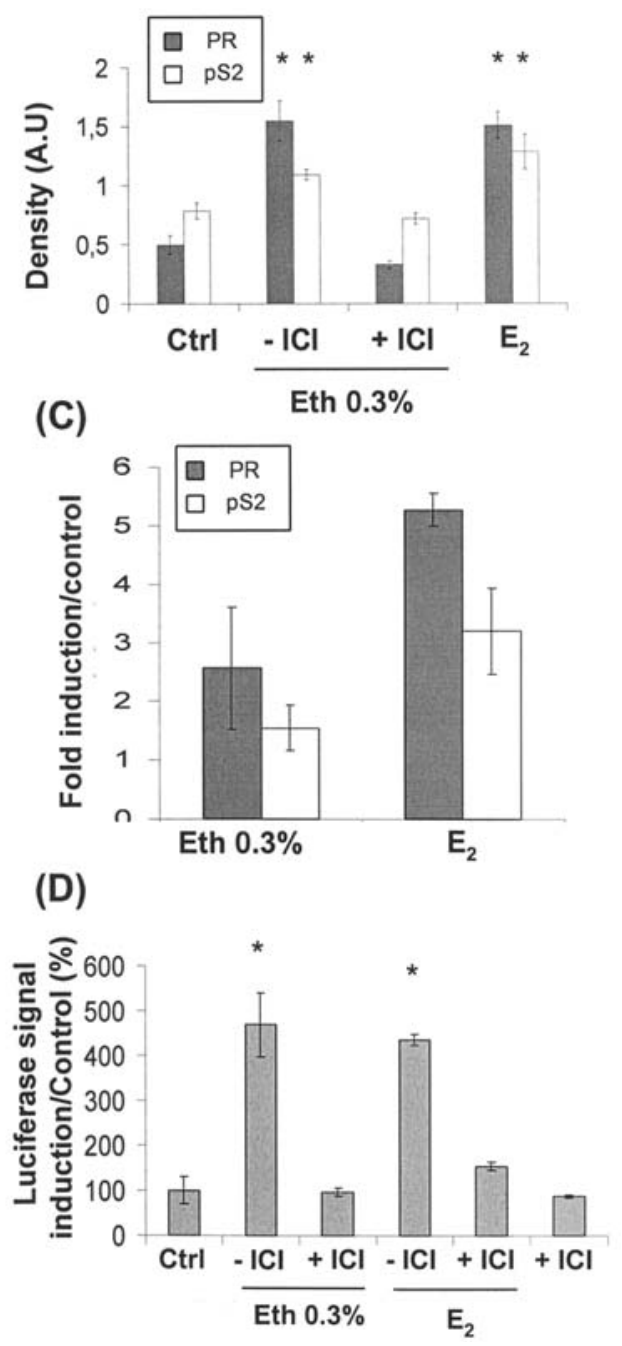

Figure 3. ER $\alpha$ activation by ethanol also occurs in steroid-free medium. (A) Semi-quantitative RT-PCR analysis of PR and pS2 mRNAs. MCF-7 cells were treated for $24 \mathrm{~h}$ in serum-free medium supplemented with $0.3 \%$ ethanol (Eth) or $1 \mathrm{nmol} / 1 \mathrm{E}_{2}$, in the presence or absence of $10 \mu \mathrm{mol} / 1 \mathrm{ICI} 182,780$ (ICI). $\beta$-actin mRNA levels were determined as an internal control. For each gene, the amplification took place in the linear phase of the PCR reaction. (B) The histogram represents the mean $\pm \mathrm{SE}$ of four separate experiments in which the band intensities of PR and pS2 were evaluated in terms of optical density arbitrary units (AU) and normalized with the $\beta$-actin signal intensity. (C) The histogram represents the mean $\pm \mathrm{SE}$ of real-time RT-PCR analyses of PR and $\mathrm{pS} 2$ expressions in MCF-7 cells that were grown in serum-free medium and treated for $24 \mathrm{~h}$ with ethanol or $\mathrm{E}_{2}$ ( 6 and 3 independent replicates respectively) in comparison to control untreated cells. (D) MCF-7 cells were transiently cotransfected with pEREtkLuc and pCMV-ßGal. The cells were treated for $24 \mathrm{~h}$ with ethanol $(0.3 \%)$ or $\mathrm{E}_{2}(1 \mathrm{nmol} / \mathrm{l})$ in the presence or absence of ICI 182,780 $(10 \mu \mathrm{mol} / \mathrm{l})$. Luciferase reporter activity was measured, normalized with the $ß-$ Gal activity and expressed as percentage of the control assumed as $100 \%$. The values represent the means \pm SE of three different experiments. In each experiment, the activities of transfected plasmids were assayed in duplicate transfections. *Significantly different from untreated control $(\mathrm{P}<0.05)$. 
ethanol still increased pS2 expression significantly (1.4-fold) and to a greater extent PR expression (3.1-fold). Interestingly, these increases were similar to those observed in MCF-7 cells exposed to $1 \mathrm{nmol} / 1 \mathrm{E}_{2}$. Moreover, this ethanol-induced increase in PR and pS2 expression was inhibited by ICI 182,780 (100 nmol/l). The difference of PR expression level in cells exposed to ICI 182,780 versus control cells was not so important than in our previous experiments performed in the presence of $1 \%$ FCS. This is in agreement with the absence of steroid hormones in the medium. But again, the basal level of pS2 expression was not affected by the presence of ICI 182,780 . This reinforces the lower sensitivity of its expression to $\mathrm{E}_{2}$.

In order to confirm the transcriptional activation of ER $\alpha$ target genes by ethanol in steroid-free medium, we used two more quantitative approaches. First, real-time RT-PCR analyses showed an increase in $\mathrm{PR}$ and $\mathrm{pS} 2$ expressions (2.6and 1.5-fold respectively) in MCF-7 cells exposed to a 24-h treatment with $0.3 \%$ ethanol in serum-free medium (Fig. 3C). Again, the increase in PR expression was higher than those observed for $\mathrm{pS} 2$. An increase in the expression of both genes was also observed in $\mathrm{E}_{2}$-treated cells $(1 \mathrm{nmol} / \mathrm{l}), \mathrm{PR}$ showing a higher sensitivity than $\mathrm{pS} 2$ (5.3 and 3.2 fold respectively) (Fig. 3C).

In the second approach, MCF-7 cells were grown in medium containing $10 \%$ FCS stripped in dextran-coated charcoal and transiently transfected with the reporter construct pEREtkLuc. They were treated for $24 \mathrm{~h}$ with $0.3 \%$ ethanol in presence or absence of ICI 182,780 (100 nmol/l), respectively. In these conditions, ethanol treatment significantly increased luciferase activity (4.6-fold) with an intensity similar to $E_{2}$ (4.4-fold) and these stimulatory effects were inhibited by ICI 182,780 (Fig. 3D). Hence, we hypothesized that ethanol treatment triggered a ligand-independent activation of ER $\alpha$.

To confirm this hypothesis, we have studied changes in $\mathrm{ER} \alpha$ protein content by Western immunoblotting (Fig. 4). Indeed, it is well known that the binding of $E_{2}$ to $E R \alpha$ rapidly decreases ER $\alpha$ protein levels, which is required for the increase in transcriptional activity (38). Ligand-induced ER $\alpha$ degradation also occurs upon treatment with the isomer $17 \alpha-E_{2}$ as well as antiestrogens such as ICI 182,780 even though these compounds are unable to activate $\operatorname{ER} \alpha(37,38)$. Like in our RT-PCR analyses, MCF-7 cells were treated for $24 \mathrm{~h}$, in serum-free condition, with ethanol $(0.3 \%)$ or $\mathrm{E}_{2}$ ( $1 \mathrm{nmol} / \mathrm{l})$ in presence or absence of ICI $182,780(100 \mathrm{nmol} / \mathrm{l})$. In the presence of E2 or ICI 182,780, we observed a decrease in $\mathrm{ER} \alpha$ protein level. In contrast, $\mathrm{ER} \alpha$ protein level remained constant in ethanol-treated cells. This result confirmed that ethanol-induced ER $\alpha$ activation was ligand-independent.

Ethanol-induced ERa activation is mediated by the cyclic AMP/PKA pathway. In breast cancer cells, ligand-independent $\mathrm{ER} \alpha$ activation can be mediated by several kinase pathways including the MAPK and PKA (12-15). Since ethanol exposure induces an increase in cyclic AMP in MCF-7 cells, we examined PKA (25). Estrogen-responsive gene expression was studied by semi-quantitative RT-PCR in MCF-7 cells that were treated with ethanol $(0.3 \%)$ for $24 \mathrm{~h}$, in serum-free condition, in presence or absence of H89 (10 $\mu \mathrm{mol} / \mathrm{l})$. The

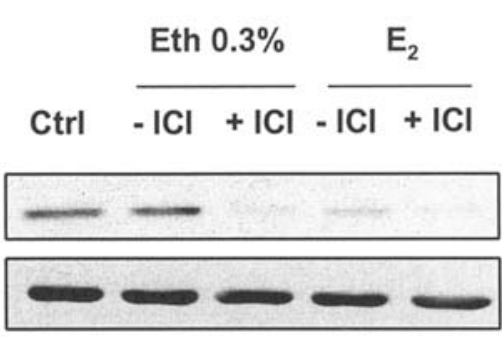

Figure 4. Absence of ER $\alpha$ proteolysis in MCF-7 cells exposed to ethanol. Immunoblot of $\mathrm{ER} \alpha$ from MCF-7 cells treated in serum-free condition with ethanol $(0.3 \%)$ or $\mathrm{E}_{2}(1 \mathrm{nmol} / \mathrm{l})$, in the presence and absence of ICI 182,780 $(10 \mu \mathrm{mol} / \mathrm{l})$ for $24 \mathrm{~h}$.

(A)
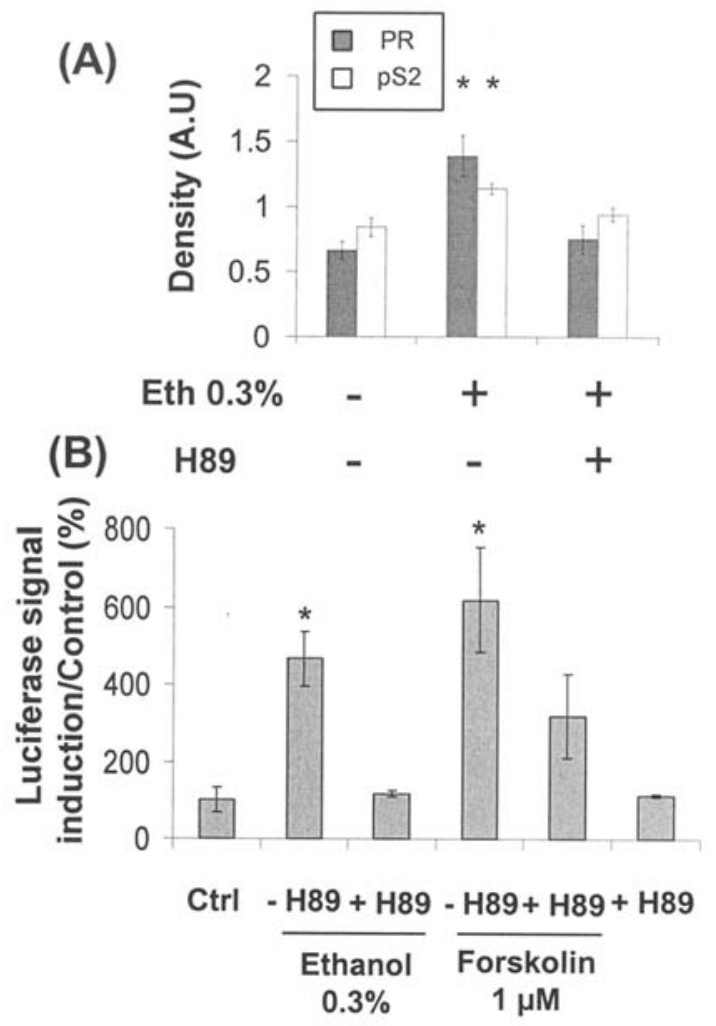

Figure 5. Ethanol-induced ER $\alpha$ activation is mediated by PKA. (A) Semiquantitative RT-PCR analysis of PR and pS2 mRNAs. MCF-7 cells were treated for $24 \mathrm{~h}$, in serum-free conditions, with $0.3 \%$ ethanol (Eth) and $10 \mu \mathrm{mol} / 1 \mathrm{H} 89$. B-actin mRNA levels were determined as an internal control. The histogram represents the mean \pm SE of four separate experiments in which the band intensities of PR and $\mathrm{pS} 2$ were evaluated in terms of optical density arbitrary units (AU) and normalized with the $B$-actin signal intensity. (B) MCF-7 cells were transiently cotransfected with pEREtkLuc and pCMV-BGal. The cells were treated for $24 \mathrm{~h}$ with ethanol $(0.3 \%)$ or Forskolin $(1 \mu \mathrm{mol} / \mathrm{l})$ in the presence or absence of $\mathrm{H} 89(10 \mu \mathrm{mol} / \mathrm{l})$. Luciferase reporter activity was measured, normalized with the $\beta-G a l$ activity and expressed as percentage of the control assumed as $100 \%$. The values represent the means $\pm \mathrm{SE}$ of three different experiments. In each experiment, the activities of transfected plasmids were assayed in duplicate transfections. . Significantly different from untreated control $(\mathrm{P}<0.05)$.

ethanol-induced increase in PR and pS2 expression was completely inhibited by the PKA inhibitor H89 (Fig. 5A). To confirm this result, MCF-7 cells were grown in medium containing $10 \%$ FCS stripped in dextran-coated charcoal and transiently transfected with the reporter construct pEREtkLuc. 


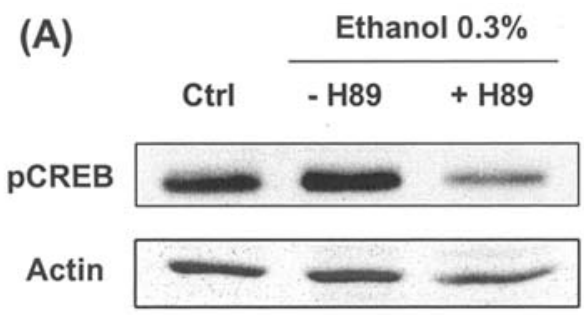

(B)

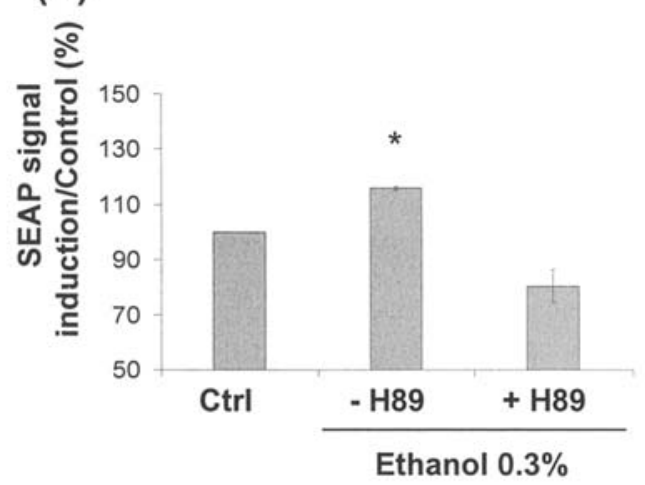

(C)

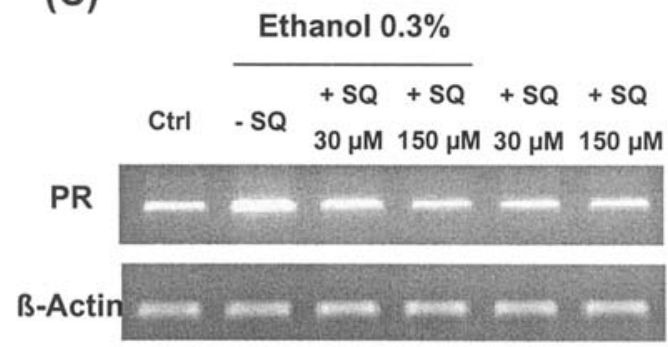

(D)

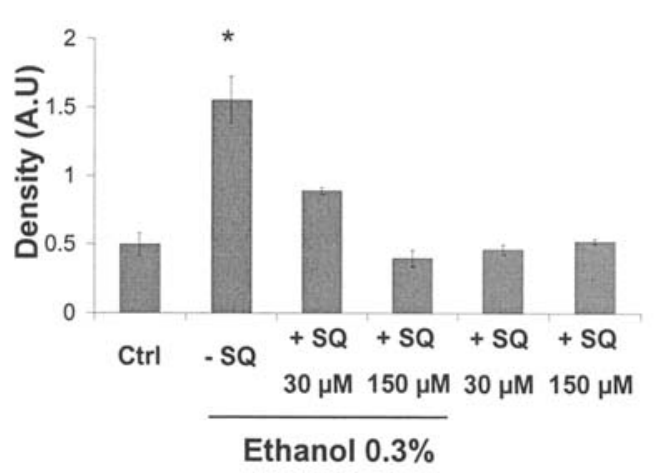

Figure 6. The cyclic AMP/PKA pathway is stimulated in MCF-7 cells exposed to ethanol. (A) Immunoblot of phosphorylated CREB (pCREB). MCF-7 cells were either untreated or treated for $24 \mathrm{~h}$ with ethanol $(0.3 \%)$ in the presence or absence of $\mathrm{H} 89$ (10 $\mu \mathrm{mol} / \mathrm{l})$. Actin serves as loading control. (B) MCF-7 cells were transiently cotransfected with pCRE-SEAP and pCMV-ßGal. The cells were treated for $24 \mathrm{~h}$ with ethanol $(0.3 \%)$ in the presence or absence of $\mathrm{H} 89(10 \mu \mathrm{mol} / \mathrm{l})$. SEAP reporter activity was measured, normalized with the ß-Gal activity and expressed as percentage of the control assumed as $100 \%$. The values represent the means \pm SE of three different experiments. In each experiment, the activities of transfected plasmids were assayed in triplicate transfections. (C) Semi-quantitative RT-PCR analysis of PR mRNA. MCF-7 cells were treated for $24 \mathrm{~h}$, in serum-free condition, with ethanol $(0.3 \%)$ and the adenylyl cyclase inhibitor SQ22536 (SQ) (30 and $150 \mu \mathrm{mol} / \mathrm{l})$. B-actin mRNA levels were determined as an internal control. For each gene, the amplification took place in the linear phase of the PCR reaction. (D) The histogram represents the mean $\pm \mathrm{SE}$ of four separate experiments in which the band intensities of PR were evaluated in terms of optical density arbitrary units (AU) and normalized with the $\beta$-actin signal intensity. * Significantly different from untreated control $(\mathrm{P}<0.05)$.
They were treated for $24 \mathrm{~h}$ with $0.3 \%$ ethanol or forskolin ( $1 \mu \mathrm{mol} / \mathrm{l})$ in presence or absence of $\mathrm{H} 89(10 \mu \mathrm{mol} / \mathrm{l})$, respectively. Ethanol and forskolin treatment significantly increased luciferase activity (Fig. 5B). H89 inhibited partially the effect of forskolin, showing the efficiency of this inhibitor. A more total inhibition could have been observed if MCF-7 cells had been pretreated with $\mathrm{H} 89$ since forskolin, which is a powerfull adenylyl cyclase stimulator, acts probably more rapidly than $\mathrm{H} 89$. In case of ethanol-treated cells, the stimulatory effect was completely abolished by the PKA inhibitor.

The inhibitory effect of $\mathrm{H} 89$ on ethanol-induced activation of ER $\alpha$ suggested that the cyclic AMP/PKA pathway was stimulated in MCF-7 cells exposed to ethanol. In order to confirm this hypothesis, we studied CREB, a transcription factor that can be activated by PKA-dependent phosphorylation of serine 133 (S133) (39). MCF-7 cells were grown during $24 \mathrm{~h}$ in serum-free medium containing $0.3 \%$ ethanol. Then, proteins from cell lysates were examined by Western blot analysis using an antibody that recognizes CREB phosphorylated at residue S133 (Fig. 6A). Ethanol induced the phosphorylation of CREB. Furthermore, cotreatment of cells with $\mathrm{H} 89$ resulted in a complete inhibition of ethanol-induced S133 phosphorylated CREB levels.

CREB activation by phosphorylation was further analyzed by its ability to interact with its DNA-response element, the CRE (cyclic AMP response element). MCF-7 cells were transiently transfected with the reporter construct pCRESEAP and treated for $24 \mathrm{~h}$ with $0.3 \%$ ethanol in presence or absence of H89 (10 $\mu \mathrm{mol} / \mathrm{l})$, respectively. Ethanol treatment significantly increased CRE-SEAP activity (Fig. 6B). This stimulatory effect was inhibited by H89. The CRE-SEAP activity was also increased by forskolin treatment $(1 \mu \mathrm{mol} / \mathrm{l})$ (data not shown). These results confirmed that ethanol was able to upregulate the activity of PKA in MCF-7 cells.

PKA activity can be activated by the binding of cyclic AMP to its regulatory subunits (40). Using a specific adenylyl cyclase inhibitor (SQ22536), we determined the involvement of this enzyme in ethanol-induced ER $\alpha$ activation. PR expression was analyzed by semi-quantitative RT-PCR in MCF-7 cells treated with ethanol $(0.3 \%)$ for $24 \mathrm{~h}$ in the presence or absence of SQ22536 in serum-free medium, respectively. The increase in PR expression usually induced by ethanol was significantly inhibited by SQ22536 (30 and $150 \mu \mathrm{mol} / \mathrm{l})$ (Fig. 6C and D).

Taken together, these results established that the ligandindependent activation of ER $\alpha$ by ethanol was mediated by the cyclic AMP/PKA pathway.

\section{Discussion}

Alcohol consumption increases the risk for breast cancer in women by still undefined pathways (16-19). A growing number of in vivo and in vitro studies have been performed in order to identify the mechanisms involved in alcohol effects $(20,21,24-31)$. One explanation could be that ethanol activates the estrogen signaling pathway which is responsible for estrogen-dependent breast cancers. Indeed, ethanol treatment stimulates the proliferation of hormone-dependent breast cancer cells (24-27). One study reported that ethanol 


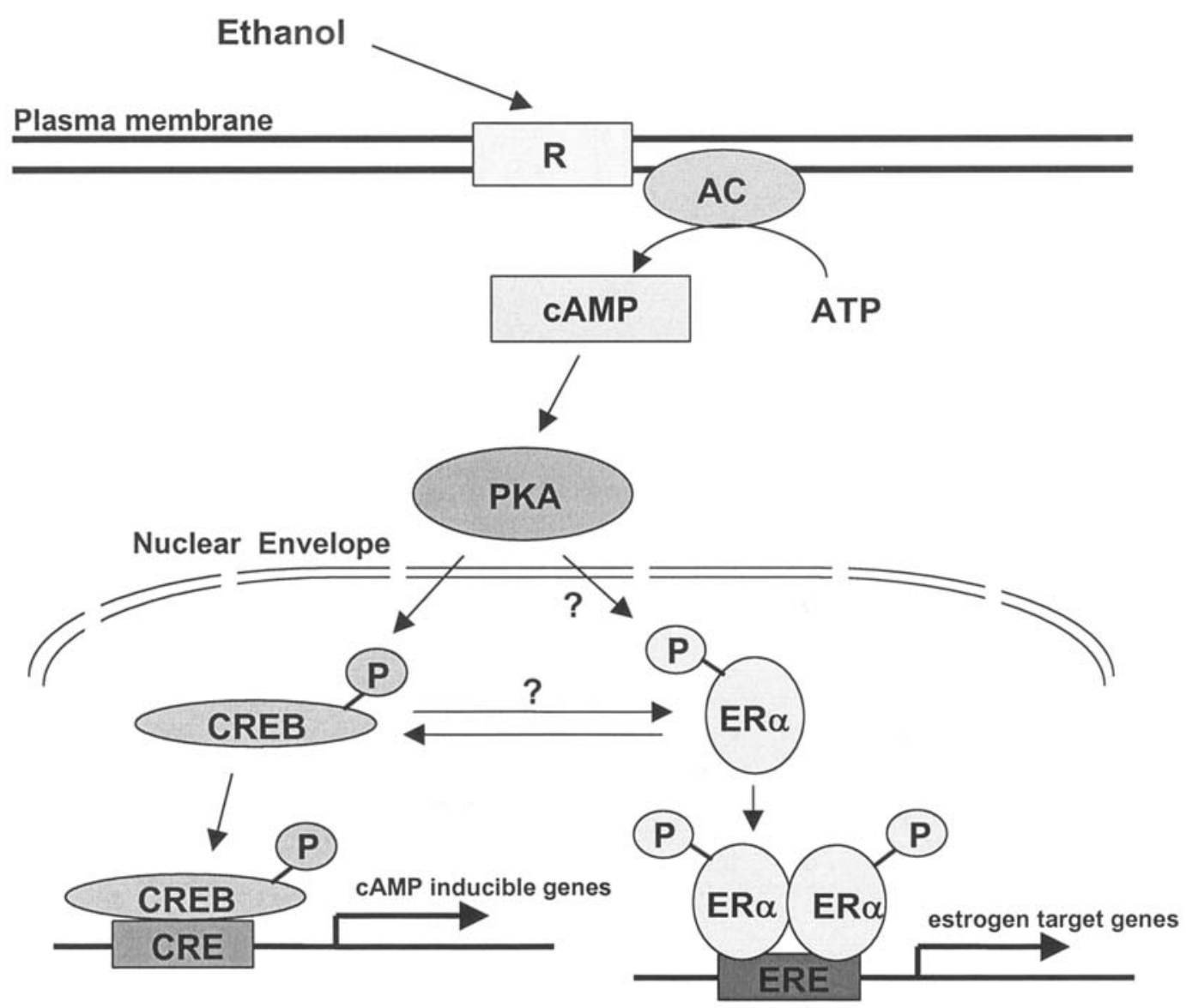

Figure 7. Schematic representation of ethanol effects in MCF-7 cells. Ethanol activates a membrane receptor (R) leading to the activation of adenylyl cyclase (AC) and the increase in intracellular cyclic AMP (cAMP) level (25). Increased cyclic AMP stimulates PKA activity which phosphorylates CREB. Phosphorylation of CREB upregulates cyclic AMP-inducible gene transcription. PKA also induces a ligand-independent activation of ER $\alpha$ either by a direct phosphorylation and/or by an interaction with phosphorylated CREB (14,51). The activated receptor then binds to specific estrogen response elements (EREs) within target genes, recruits the coactivator complex and promotes gene transcription.

could stimulate estrogen receptor signaling in human breast cancer cell lines (31). The authors showed that when MCF-7 or T-47-D cells were transfected with a plasmid containing an EREtkLuc construct and then incubated with $\mathrm{E}_{2}$ plus ethanol, there was a dose-dependent increase in $\mathrm{E}_{2}$-stimulated reporter activity. Moreover, ethanol can also stimulate breast cancer cell invasion and migration (28). We have recently observed that this might be related to an increase in MMP-2 and MMP-9 secretion (30). This effect was partially inhibited by the anti-estrogen ICI 182,780 , suggesting again an activation of ER $\alpha$ in ethanol-treated cells. The present in vitro study was performed to demonstrate the activation of $\mathrm{ER} \alpha$ in breast cancer cells incubated in ethanol containing medium and to determine the molecular bases of this activation.

First, we studied mRNA expression of two well known estrogen regulated genes: those encoding the progesterone receptor (6) and those encoding pS2 (7). Both PR and pS2 mRNAs were increased after $24 \mathrm{~h}$ of ethanol treatment, with the most efficient dose being $0.3 \%$ ethanol. The increase in $\mathrm{PR}$ and pS2 was modest but reliable since the same result was observed in numerous experiments (a mean of 5 replicates is shown for instance in Fig. 1). Moreover, the increase observed in case of ethanol exposure was always similar to those observed in response to $\mathrm{E}_{2}$. The concentration of $0.3 \%$ has been previously described to stimulate the proliferation of estrogen-dependent breast cancer cell lines, not only MCF-7 but also ZR-75-1 (24-27). No significant increase in $\mathrm{PR}$ and pS2 transcription level was observed at higher doses. One might suggest that this was due to a decreased cell viability. However, studies by the MTT dye conversion assay showed that after a $24-\mathrm{h}$ treatment, MCF-7 cell viability was not affected below $100 \mathrm{mmol} / \mathrm{l}(0.58 \%)$ ethanol (28). Nevertheless, our results showing that high doses of ethanol do not stimulate significantly the expression of $\mathrm{E}_{2}$-regulated genes are consistent with the fact that the increase in cell proliferation induced by ethanol after a 24-h exposure is not always observed at high doses of alcohol (26).

What are the molecular events responsible for the higher expression of PR and pS2 observed in MCF-7 cells incubated during $24 \mathrm{~h}$ in $0.3 \%$ ethanol? Although the expression of both genes is regulated by estrogens, other factors could be involved. For instance, the level of MCF-7 cell pS2 mRNA can also be increased by the tumor promoter 12-0-tetradecanoylphorbol-13-acetate (7). Similarly, PR expression in MCF-7 can be stimulated by several transcription factors such as HOXA5 (42). However, since the pure antiestrogen ICI 182,780 abolished the ethanol-induced increase in PR and $\mathrm{pS} 2$ expression, this clearly demonstrated the involvement of ER $\alpha$ in this phenomenon. 
Since we have previously shown that ethanol-treated MCF-7 cells displayed a higher level of aromatase (27), we hypothesized that ethanol-induced stimulation of ER $\alpha$ was the result of a local production of estrogens via aromatase. Indeed, when MCF-7 cells are cultured in a low estrogen medium and treated with aromatizable androgens, there is significant cell growth stimulation which is completely inhibited by the aromatase inhibitor letrozole (43). The increase in PR and pS2 expression can also be the consequence of the aromatization of testosterone to $E_{2}(43,44)$. Similar processes seem to occur in breast tumors and women with estrogen responsive breast cancer receive not only anti-estrogen therapy with tamoxifen but also aromatase inhibitors (45). In order to determine if steroids are required for ethanol to stimulate PR and pS2 expression, we performed experiments in steroid-free medium.

In serum-free condition, ethanol treatment $(0.3 \%)$ still increased PR and pS2 mRNA levels. The intensity of this response was similar between semi-quantitative RT-PCR and real-time RT-PCR analyses. It was similar to the intensity measured for $E_{2}(1 \mathrm{nmol} / \mathrm{l})$ in semi-quantitative RT-PCR whereas it was lower than those of $\mathrm{E}_{2}$ in real-time RT-PCR experiments. Whatever the method (semi-quantitative or realtime RT-PCR) and the stimulating compound ( $0.3 \%$ ethanol or $\mathrm{E}_{2}$ ), the increase in pS2 mRNA level was always lower than those observed for PR. The response observed for PR was higher in serum-free medium than in FCS-containing medium with ethanol or $\mathrm{E}_{2}$ whereas $\mathrm{pS} 2$ response was similar in both conditions. Our result on PR expression in response to $E_{2}$ is consistent with the higher sensitivity of MCF-7 cells to this steroid in terms of cell proliferation, that has already been reported in newborn calf serum versus fetal calf serum containing medium, the latter containing a higher concentration of steroids (43). In stripped serum condition, ethanol treatment $(0.3 \%)$ increased luciferase activity of pEREtkLuc transfected MCF-7 cells, with an efficiency similar to those observed for $\mathrm{E}_{2}(1 \mathrm{nmol} / \mathrm{l})$. The confirmation by real-time RT-PCR analyses and transfection assays of ethanol effects deduced from semi-quantitative RT-PCR experiments is important. Indeed, these methods are quantitative and moreover, it demonstrates definitely the involvement of an ERE-mediated effect of ethanol.

The induction of $E_{2}$ target gene expression by ethanol in steroid-free medium suggested that these hormones, especially estrogens, were not involved in this mechanism. However, the inhibition of ethanol effect by ICI 182,780 prompted us to hypothesize that ER $\alpha$ was still implicated. Then we proposed that ethanol treatment leads to a ligand-independent activation of the receptor. Indeed, ER $\alpha$ activation can occur without any estrogen in the culture medium and then is dependent on several kinase pathways including the MAPK and PKA pathways (12-15). To confirm our hypothesis, we analyzed the ER $\alpha$ protein content by Western blotting. Indeed, it is well described that $\mathrm{ER} \alpha$ is downregulated in the presence of its cognate ligand $E_{2}$, as well as in the presence of antiestrogens, through the ubiquitin proteasome pathway $(38,46)$. On the contrary, ligand-independent stimulation of ER $\alpha$ transcription by the PKA pathway does not lead to receptor degradation (47). Western immunoblot analyses showed that in MCF-7 cells incubated for $24 \mathrm{~h}$ in ethanol containing medium, the ER $\alpha$ protein level was similar to those of control cells. The lower ER $\alpha$ detection observed in $\mathrm{E}_{2}$-treated cells as well as in ICI 182,780-treated cells was consistent with other studies showing that ER $\alpha$ proteolysis is triggered by treatment with ER $\alpha$ ligands, with a faster and higher efficiency observed for ICI 182,780 than for $E_{2}$ itself (48). This absence of ER $\alpha$ proteolysis following exposure to ethanol confirmed our hypothesis of a ligand-independent activation of the receptor.

The use of the selective inhibitor of PKA (H89) allowed us to identify the kinase pathway involved in this mechanism. H89 abolished completely the increase in PR and pS2 mRNA levels induced by ethanol. The activation of PKA by ethanol was confirmed by several analyses. It is well known that CREB is activated by PKA (49). An antibody raised against phosphorylated CREB (at Ser 133) detected a higher amount of phospho-CREB in ethanol-treated MCF-7 cells. An event downstream of CREB phosphorylation is its association to CREB-binding protein (CBP) and the subsequent transcription of target genes with CRE in their promoter. As expected, ethanol stimulated the expression of the SEAP reporter gene in MCF-7 cells transfected with a CRE-SEAP construct. These findings are consistent with the fact that treatment of MCF-7 cells with PKA activators stimulates pS2 transcription in the absence of detectable estrogens $(50,51)$. They are also in agreement with our results showing that forskolin is able to increase luciferase activity in pEREtkLuc transfected MCF-7 cells. The nature of the relationship between PKA and ER $\alpha$ in ethanol-treated MCF-7 cells remains to be elucidated. We questioned whether ER $\alpha$ activation requires its association with other partners like PKA phosphorylated-CREB and CBP or whether PKA directly phosphorylate $\mathrm{ER} \alpha(14,52)$. Since it has been shown that forskolin-triggered PKA activation protects ER $\alpha$ from ligand-mediated degradation (47), we rather agree with the second hypothesis. Indeed, a 6-day ethanol exposure in serum-containing medium (1\%) increases the ER $\alpha$ protein content which could be the result of a reduced proteolysis (27). Nevertheless, the use of an antibody raised against a phosphorylated synthetic peptide which represented a portion of $\mathrm{ER} \alpha$ around serine 305 that is included in a consensus sequence for PKA phosphorylation (Bethyl Laboratories Inc.), did not allow us to definitely conclude on ER $\alpha$ phosphorylation. In addition, a stimulation of ER-target gene expression was always observed after $24 \mathrm{~h}$ of ethanol exposure whereas at a shorter timepoint $(8 \mathrm{~h})$, a high variability in this response of MCF-7 cells to alcohol was observed (not shown). This suggests that the increase in ER $\alpha$ target genes is an indirect event downstream of PKA activation. Additional studies are needed to elucidate that point.

Our results showing the activation of PKA are in agreement with a previous study showing an increase in cyclic AMP in MCF-7 and T47-D breast cancer cells exposed to ethanol (25). Furthermore, using an inhibitor of adenylyl cyclase (SQ22536), we observed a blockade of ethanol-induced increase of PR mRNA expression in MCF-7 cells. Adenylyl cyclase can be activated by $\mathrm{G}$ protein-coupled membrane receptors. Interestingly, ethanol has been reported to stimulate cyclic AMP production in both neuroblastoma $\mathrm{x}$ glioma hybrid cells (NG 108-15) and lymphoma cells via the 
$\mathrm{A}_{2 \mathrm{a}} \mathrm{AR}$ (41). A similar process could be involved in ethanoltreated MCF-7 cells.

What is the relevance to humans of our in vitro studies? In regard to alcohol consumption, it can be reminded that according to Widmark formula, a woman drinking $0.6 \mathrm{~g}$ alcohol per $\mathrm{kg}$ of body weight over a one-hour period has blood ethanol concentrations of approximately $0.1 \%$ one hour later (54). So, a $65-\mathrm{kg}$ woman needs to drink $39 \mathrm{~g}$ alcohol (approximately 0.51 of wine) to have a blood ethanol concentration of $0.1 \%$. Obviously, studies of lethal dosage cannot be tested empirically in the laboratory, so the LD:50 for alcohol is estimated from post-mortem cases in which alcohol poisoning was found to be the primary cause of death. Most authorities agree that blood alcohol concentrations in the $0.40-0.50 \%$ range meet the requirements for the LD:50. So, the concentration of $0.3 \%$ used in most of our experiments, due to the higher intensity of its effect, could be considered as too high to mimic the in vivo situation. Nevertheless, we also observed the stimulation of estrogen target genes expression in response to $0.1 \%$ ethanol (Fig. 1), a concentration that is in the range of those measured in vivo following alcohol consumption. Besides, an increase in MCF-7 cyclic AMP content was also described in case of treatment with a concentration of $0.15 \%$ (25). The stimulatory effects of ethanol on breast cancer cell proliferation are also observed at $0.1 \%$ (24-27). Our study indicates that ethanol can be considered as a tool to study in vitro molecular mechanisms. In that context, high doses of ethanol are often used: for instance $100 \mathrm{mM}$ (i.e. $0.6 \%$ ) to study adenosine uptake in human lymphoblastoid cell lines (42). Ethanol could be an interesting tool to study ER and especially the ligandindependent activation that we have shown here.

In conclusion, our study demonstrates that ethanol treatment of MCF-7 breast cancer cells stimulates the cyclic AMP/PKA pathway which triggers two important events: an increase in the expression of genes with CRE in their promoter, like aromatase $(27,55)$ as well as a ligand-independent activation of ER $\alpha$ and transcription of target genes (Fig. 7). Both events could have a dramatic effect on breast cancer cells since estrogen signaling pathway plays a key role in their physiology.

\section{Acknowledgements}

We acknowledge Professor Didier PICARD (University of Geneva, Switzerland) for the generous gift of pEREtkLuc vector and Doctors M. Duterque-Coquillaud and F. Küpper for critical reading of the manuscript. This work was supported by 'Université Henri Poincaré (BQR)', 'Ligue Contre le Cancer, comités de la Meurthe et Moselle, de la Meuse et de la Haute-Marne', 'Association pour la Recherche sur le Cancer', 'Cancéropôle Grand Est', 'Institut de Recherches Scientifiques sur les Boissons' and 'Conseil Régional de Lorraine'.

\section{References}

1. Weichselbaum RR, Hellman S, Piro AJ, Nove JJ and Little JB: Proliferation kinetics of a human breast cancer line in vitro following treatment with 17 beta-estradiol and 1-beta-Darabinofuranosylcytosine. Cancer Res 38: 2339-2342, 1978.
2. Reddel RR and Sutherland RL: Tamoxifen stimulation of human breast cancer cell proliferation in vitro: a possible model for tamoxifen tumour flare. Eur J Cancer Clin Oncol 20: 1419-1424, 1984

3. Lykkesfeldt AE and Briand P: Indirect mechanism of oestradiol stimulation of cell proliferation of human breast cancer cell lines. Br J Cancer 53: 29-35, 1986.

4. Hall JM and McDonnell DP: Coregulators in nuclear estrogen receptor action: from concept to therapeutic targeting. Mol Interv 5: 343-357, 2005 .

5. Singh RR and Kumar R: Steroid hormone receptor signaling in tumorigenesis. J Cell Biochem 2005, 96: 490-505, 2005.

6. Kumar V, Green S, Stack G, Berry M, Jin JR and Chambon P: Functional domains of the human estrogen receptor. Cell 51: 941-951, 1987.

7. Nunez AM, Berry M, Imler JL and Chambon P: The 5' flanking region of the pS2 gene contains a complex enhancer region responsive to oestrogens, epidermal growth factor, a tumour promoter (TPA), the c-Ha-ras oncoprotein and the c-jun protein. EMBO J 8: 823-829, 1989.

8. Gaub MP, Bellard M, Scheuer I, Chambon P and SassoneCorsi P: Activation of the ovalbumin gene by the estrogen receptor involves the fos-jun complex. Cell 63: 1267-1276, 1990 .

9. De Nardo DG, Kim HT, Hilsenbeck S, Cuba V, Tsimelzon A and Brown PH: Global gene expression analysis of estrogen receptor transcription factor cross talk in breast cancer: identification of estrogen-induced/activator protein-1-dependent genes. Mol Endocrinol 19: 362-378, 2005.

10. Xie W, Duan R and Safe S: Estrogen induces adenosine deaminase gene expression in MCF-7 human breast cancer cells: role of estrogen receptor-Sp1 interactions. Endocrinology 140: 219-227, 1999

11. Coleman KM and Smith CL: Intracellular signaling pathways: nongenomic actions of estrogens and ligand-independent activation of estrogen receptors. Front Biosci 6: D1379-D1391, 2001.

12. Kato S, Endoh H, Masuhiro Y, Kitamoto T, Uchiyama S, Sasaki H, Masushige S, Gotoh Y, Nishida E, Kawashima H, Metzger D and Chambon P: Activation of the estrogen receptor through phosphorylation by mitogen-activated protein kinase. Science 270: 1491-1494, 1995.

13. Bunone G, Briand PA, Miksicek RJ and Picard D: Activation of the unliganded estrogen receptor by EGF involves the MAP kinase pathway and direct phosphorylation. EMBO J 15: 2174-2183, 1996.

14. Le Goff P, Montano MM, Schodin DJ and Katzenellenbogen BS: Phosphorylation of the human estrogen receptor. Identification of hormone-regulated sites and examination of their influence on transcriptional activity. J Biol Chem 269: 4458-4466, 1994.

15. Aronica SM, Kraus WL and Katzenellenbogen BS: Estrogen action via the cAMP signaling pathway: stimulation of adenylate cyclase and cAMP-regulated gene transcription. Proc Natl Acad Sci USA 91: 8517-8521, 1994.

16. Longnecker MP: Alcoholic beverage consumption in relation to risk of breast cancer: meta-analysis and review. Cancer Causes Control 5: 73-82, 1994.

17. Aronson K: Alcohol: a recently identified risk factor for breast cancer. CMAJ 168: 1147-1148, 2003.

18. Ma H, Bernstein L, Ross RK and Ursin G: Hormone-related risk factors for breast cancer in women under age 50 years by estrogen and progesterone receptor status: results from a casecontrol and a case-case comparison. Breast Cancer Res 8: R39, 2006.

19. Rosenberg LU, Magnusson C, Lindstrom E, Wedren S, Hall P and Dickman PW: Menopausal hormone therapy and other breast cancer risk factors in relation to the risk of different histological subtypes of breast cancer: a case-control study. Breast Cancer Res 8: R11, 2006.

20. Singletary KW, McNary MQ, Odoms AM, Nelshoppen J and Wallig MA: Ethanol consumption and DMBA-induced mammary carcinogenesis in rats. Nutr Cancer 16: 13-23, 1991.

21. Singletary K, Nelshoppen J and Wallig M: Enhancement by chronic ethanol intake of $\mathrm{N}$-methyl-N-nitrosourea-induced rat mammary tumorigenesis. Carcinogenesis 16: 959-964, 1995.

22. Reichman ME, Judd JT, Longcope C, Schatzkin A, Clevidence BA, Nair PP, Campbell WS and Taylor PR: Effects of alcohol consumption on plasma and urinary hormone concentrations in premenopausal women. J Natl Cancer Inst 85: 722-727, 1993. 
23. Dorgan JF, Baer DJ, Albert PS, Judd JT, Brown ED, Corle DK, Campbell WS, Hartman TJ, Tejpar AA, Clevidence BA, Giffen CA, Chandler DW, Stanczyk FZ and Taylor PR: Serum hormones and the alcohol-breast cancer association in postmenopausal women. J Natl Cancer Inst 93: 710-715, 2001.

24. Przylipiak A, Rabe T, Hafner J, Przylipiak M and Runnebaum R: Influence of ethanol on in vitro growth of human mammary carcinoma cell line MCF-7. Arch Gynecol Obstet 258: 137-140, 1996.

25. Singletary KW, Frey RS and Yan W: Effect of ethanol on proliferation and estrogen receptor-alpha expression in human breast cancer cells. Cancer Lett 165: 131-137, 2001.

26. Izevbigie EB, Ekunwe SI, Jordan J and Howard CB: Ethanol modulates the growth of human breast cancer cells in vitro. Exp Biol Med 227: 260-265, 2002.

27. Etique N, Chardard D, Chesnel A, Merlin JL, Flament S and Grillier-Vuissoz I: Ethanol stimulates proliferation, ERalpha and aromatase expression in MCF-7 human breast cancer cells. Int J Mol Med 13: 149-155, 2004.

28. Meng Q, Gao B, Goldberg ID, Rosen EM and Fan S: Stimulation of cell invasion and migration by alcohol in breast cancer cells. Biochem Biophys Res Commun 273: 448-453, 2000.

29. Luo J and Miller MW: Ethanol enhances erbB-mediated migration of human breast cancer cells in culture. Breast Cancer Res Treat 63: 61-69, 2000.

30. Etique N, Grillier-Vuissoz I and Flament S: Ethanol stimulates the secretion of matrix metalloproteinases 2 and 9 in MCF-7 human breast cancer cells. Oncol Rep 15: 603-608, 2006.

31. Fan S, Meng Q, Gao B, Grossman J, Yadegari M, Goldberg ID and Rosen EM: Alcohol stimulates estrogen receptor signaling in human breast cancer cell lines. Cancer Res 60: 5635-5639, 2000.

32. Fazzari A, Catalano MG, Comba A, Becchis M, Raineri M, Frairia $\mathrm{R}$ and Fortunati N: The control of progesterone receptor expression in MCF-7 breast cancer cells: effects of estradiol and sex hormone-binding globulin (SHBG). Mol Cell Endocrinol 172: 31-36, 2001

33. Catalano S, Mauro L, Marsico S, Giordano C, Rizza P, Rago V, Montanaro D, Maggiolini M, Panno ML and Ando S: Leptin induces, via ERK1/ERK2 signal, functional activation of estrogen receptor alpha in MCF-7 cells. J Biol Chem 279: 19908-19915, 2004.

34. Pfaffl MW: Quantification strategies in real-time PCR. In A-Z of Quantitative PCR. Bustin SA (ed). IUL Biotechnology Series, La Jolla, CA, International University Line: 87-120, 2004.

35. Souaze F, Ntodou-thome A, Tran CY, Rostene W and Forgez P: Quantitative Rt-PCR: limits and accuracy. Biotechniques 21: 280-285, 1996.

36. Wakeling AE and Bowler J: ICI 182,780, a new antioestrogen with clinical potential. J Steroid Biochem Mol Biol 43: 173-177, 1992.

37. Wijayaratne AL and McDonnell DP: The human estrogen receptor-alpha is a ubiquitinated protein whose stability is affected differentially by agonists, antagonists, and selective estrogen receptor modulators. J Biol Chem 276: 35684-35692, 2001 .

39. Shaywitz AJ and Greenberg ME: CREB: a stimulus-induced transcription factor activated by a diverse array of extracellular signals. Annu Rev Biochem 68: 821-861, 1999.

40. Herberg FW, Taylor SS and Dostmann WR: Active site mutations define the pathway for the cooperative activation of cAMP-dependent protein kinase. Biochemistry 35: 2934-2942, 1996.
41. Nagy LE, Diamond I, Casso DJ, Franklin C and Gordon AS Ethanol increases extracellular adenosine by inhibiting adenosine uptake via the nucleoside transporter. J Biol Chem 265 1946-1951, 1990

42. Raman V, Tamori A, Vali M, Zeller K, Korz D and Sukumar S HOXA5 regulates expression of the progesterone receptor. J Biol Chem 275: 26551-26555, 2000.

43. Sonne-Hansen K and Lykkesfeldt AE: Endogenous aromatization of testosterone results in growth stimulation of the human MCF-7 breast cancer cell line. J Steroid Biochem Mol Biol 93: 25-34, 2005.

44. Burak WE Jr, Quinn AL, Farrar WB and Brueggemeier RW: Androgens influence estrogen-induced responses in human breast carcinoma cells through cytochrome P450 aromatase. Breast Cancer Res Treat 44: 57-64, 1997.

45. Nabholtz JM, Buzdar A, Pollak M, Harwin W, Burton G, Mangalik A, Steinberg M, Webster A and von Euler M: Anastrozole is superior to tamoxifen as first-line therapy for advanced breast cancer in postmenopausal women: results of a North American multicenter randomized trial. Arimidex Study Group. J Clin Oncol 18: 3758-3767, 2000.

46. Preisler-Mashek MT, Solodin N, Stark BL, Tyriver MK and Alarid ET: Ligand-specific regulation of proteasome-mediated proteolysis of estrogen receptor-alpha. Am J Physiol Endocrinol Metab 282: E891-E898, 2002.

47. Tsai HW, Katzenellenbogen JA, Katzenellenbogen BS and Shupnik MA: Protein kinase A activation of estrogen receptor alpha transcription does not require proteasome activity and protects the receptor from ligand-mediated degradation. Endocrinology 145: 2730-2738, 2004.

48. Marsaud V, Gougelet A, Maillard S and Renoir JM: Various phosphorylation pathways, depending on agonist and antagonist binding to endogenous estrogen receptor alpha (ERalpha), differentially affect ERalpha extractability, proteasome-mediated stability, and transcriptional activity in human breast cancer cells. Mol Endocrinol 17: 2013-2027, 2003.

49. Dash PK, Karl KA, Colicos MA, Prywes R and Kandel ER: cAMP response element-binding protein is activated by $\mathrm{Ca}^{2+}$ calmod. Proc Natl Acad Sci USA 88: 5061-5065, 1991.

50. Chalbos D, Philips A, Galtier F and Rochefort H: Synthetic antiestrogens modulate induction of $\mathrm{pS} 2$ and cathepsin-D messenger ribonucleic acid by growth factors and adenosine 3',5'-monophosphate in MCF7 cells. Endocrinology 133: 571-576, 1993.

51. El Tanani MK and Green CD: Interaction between estradiol and cAMP in the regulation of specific gene expression. Mol Cell Endocrinol 124: 71-77, 1996.

52. Lazennec G, Thomas JA and Katzenellenbogen BS: Involvement of cyclic AMP response element binding protein (CREB) and estrogen receptor phosphorylation in the synergistic activation of the estrogen receptor by estradiol and protein kinase activators. J Steroid Biochem Mol Biol 77: 193-203, 2001.

53. Mujoomdar M, Bennett A, Hoskin D and Blay J: Adenosine stimulation of proliferation of breast carcinoma cell lines: evaluation of the $\left[{ }^{3} \mathrm{H}\right]$ thymidine assay system and modulatory effects of the cellular microenvironment in vitro. J Cell Physiol 201: 429-438, 2004

54. Gubala W and Zuba D: Gender differences in the pharmacokinetics of ethanol in saliva and blood after oral ingestion. Pol J Pharmacol 55: 639-644, 2003.

55. Michael MD, Michael LF and Simpson ER: A CRE-like sequence that binds CREB and contributes to CAMP-dependent regulation of the proximal promoter of the human aromatase P450 (CYP19) gene. Mol Cell Endocrinol 134: 147-156, 1997. 